\title{
Robert Pietrzykowski
}

Szkoła Główna Gospodarstwa Wiejskiego w Warszawie

e-mail: robert_pietrzykowski@sggw.pl

\section{PRZESTRZENNA KONWERGENCJA WYDAJNOŚCI PRACY W ROLNICTWIE POLSKI NA POZIOMIE WOJEWÓDZTW SPATIAL CONVERGENCE OF LABOR PRODUCTIVITY IN AGRICULTURE OF POLAND ON THE NUTS2 LEVEL}

DOI: $10.15611 /$ pn.2017.487.20

JEL Classification: C21, J24, O47, O52, Q10

Streszczenie: W pracy badano konwergencję dla wydajności pracy w rolnictwie, wykorzystując modele, które ujmują w swojej strukturze efekty przestrzenne. Wykorzystano również współczynnik korelacji Morana w celu określenia reżimów przestrzennych dla badanych obiektów. Dane do analizy pochodziły z baz danych Eurostatu z okresu od 2004 do 2013. Ze względu na brak prac, które uwzględniałyby efekt przestrzenny dla wydajności pracy w rolnictwie w Polsce na poziomie NUTS2, jako cel pracy przyjęto ujęcie przestrzenne procesu konwergencji. W prowadzonych analizach konwergencję wydajności pracy rozumiano jako wyrównywanie się poziomu produktywności w polskim rolnictwie na poziomie województw.

Słowa kluczowe: konwergencja, modele przestrzenne, reżimy przestrzenne.

Summary: This study investigates the convergence of labor productivity in agriculture using spatial models. The coefficient of Moran correlation is used to determine the spatial regimes for the examined objects. The data for the analysis were derived from Eurostat databases for the period from 2004 to 2013. Due to the lack of work taking into account the spatial effect on agricultural productivity in Poland on the NUTS2 level, the objective of the work was a spatial approach to the convergence process.

Keywords: convergence, spatial models, spatial regimes.

\section{Wstęp}

W ostatnich latach zauważa się zwiększone zainteresowanie problematyką dotyczącą zbieżności poziomu wydajności pracy w rolnictwie. Powodem takiej sytuacji możne być intensyfikacja procesów gospodarczych oraz coraz większa globaliza- 
cja. W niniejszym opracowaniu konwergencja wydajności pracy rozumiana jest jako wyrównywanie się poziomu produktywności w polskim rolnictwie na poziomie województw.

Rozważania dotyczące konwergencji w sensie ekonomicznym, określanej jako efekt doganiania przez kraje biedniejsze państw bogatszych, w swoich początkach brały pod uwagę zmniejszania się dysproporcji pomiędzy dochodem bądź produktem narodowym brutto. Obecnie zmniejszanie różnic w PKB per capita pomiędzy obiektami jest utożsamiane z konwergencją gospodarczą. Natomiast coraz częściej prowadzone są badania, w których bada się zmniejszanie różnic ze względu na różne cechy - nie tylko takie, które można zaliczyć do cech gospodarczych, ale również innych, np. społecznych. Należy również zauważyć, że w swoich początkach badania dotyczące konwergencji prowadzone były na poziomie makro, tzn. państw. W ostatniej dekadzie analizowano proces konwergencji, schodząc na niższy poziom agregacji, prowadząc badania regionalne [Baer-Nawrocka, Markiewicz 2012].

Na zmiany zachodzące $\mathrm{w}$ państwach lub ich regionach należy również patrzeć w perspektywie przestrzennej ze względu na możliwość występowania zależności pomiędzy sąsiadującymi ze sobą obiektami (tzn. państwami, regionami, landami, województwami itp.). Jest to szczególnie widoczne w sytuacji powszechnej globalizacji. Prace dotyczące konwergencji wydajności pracy w rolnictwie były prowadzone między innymi przez Baer-Nawrocką [Baer-Nawrocka, Markiewicz 2012], ale nie uwzględniały efektów przestrzennych. Dlatego jako cel pracy przyjęto przestrzenne ujęcie procesu konwergencji dla wydajności pracy w rolnictwie Polski na poziomie województw (NUTS2).

\section{Proces konwergencji w badaniach}

Zagadnienie konwergencji jest często podejmowane i rozważane przez wielu autorów. Początek rozważań związanych z tym tematem można przypisać Williamowi Baumolowi, który w 1986 roku zajął się tym zagadnieniem [Baumol 1986]. Jednak początku tego zagadnienia należałoby poszukiwać znacznie wcześniej, w klasycznym ujęciu problemów wzrostu i rozwoju gospodarczego oraz hipotezie Gerschenkrona, który mówił o efekcie doganiania państw wysokorozwiniętych przez państwa słabo rozwinięte na poziomie gospodarczym [Gerschenkron 1962].

Rozwój badań w tym kierunku spowodował powstanie wielu definicji i interpretacji hipotezy dotyczącej konwergencji. Klasyczne koncepcje dotyczą konwergencji $\beta$, którą dzieli się na absolutną (bezwarunkową) i warunkową, oraz konwergencję typu $\sigma$. Podział na te dwa typy konwergencji zaproponował w 1990 roku Sala-i-Martin w pracy doktorskiej On Growth and States. Później rozwinął on zagadnienie konwergencji, prowadząc badania nad konwergencją absolutną i warunkową z Barro [Barro, Sala-i-Martin 1992]. W konsekwencji według systematyki Sala-i-Martina konwergencję absolutną typu $\beta$ można określić jako konwergencję gospodarczą, natomiast konwergencję warunkową ujmuje się jako rozwinięcie modelu Solowa- 
-Swana [Sala-i-Martin 1996]. Konwergencja warunkowa typu $\beta$ różni się między innymi tym od konwergencji absolutnej, że zawiera dodatkowe zmienne objaśniające, np. wskaźnik bezrobocia, scholaryzacji, deficyt fiskalny, wskaźniki zatrudnienia w różnych sektorach gospodarki. Poza tym w literaturze przedmiotu rozróżnia się podział na konwergencję nominalną i realną, a także ze względu na przebieg procesu konwergencji w zakresie przestrzennym - na konwergencję międzykrajową (zewnętrzną) i wewnątrzkrajową (wewnętrzną) [Kisiała 2016]. Nawiązując do powyższych rozważań, prowadzone badania procesu konwergencji ze względu na charakter analizowano $w$ ujęciu przekrojowo-czasowym [Mankiw i in. 1992] i panelowym [Knight i in. 1993]. Dalszy kierunek rozwoju hipotez związanych z konwergencją został skierowany na analizę przestrzenną, słusznie bowiem uznano, że na zmiany zachodzące w państwie mogą mieć wpływ regiony sąsiadujące [Anselin, Rey 1997; Rey 2001]. Badania dotyczące konwergencji w swoich początkach obejmowały przede wszystkim zmiany PKB lub dochody na poziomie państw. W ostatniej dekadzie zaczęto badać konwergencję ze względu na inne cechy nie tylko ekonomiczne, ale również społeczne i biologiczne. Jak wspomniano wcześniej, zmiany zaczęły też dotyczyć poziomu agregacji (konwergencja wewnętrzna). Należy tu wymienić również wielu polskich autorów, którzy badali zjawisko konwergencji np. Gawlikowska-Hueckel [2002], Ciołek [2003], Wójcik [2004], Kossowski [2009], Modranka [2012], Wicki [2012], Olejnik [2014] i wielu innych ${ }^{1}$.

\section{Metody badań}

Możemy mówić o występowaniu $\beta$-konwergencji, jeżeli współczynnik wzrostu badanego zjawiska jest ujemnie skorelowany z bazowym poziomem zjawiska. W ujęciu matematycznym zjawisko konwergencji możemy zatem zapisać w postaci liniowej funkcji regresji o postaci:

$$
\ln \left(\frac{y_{i t}}{y_{i 0}}\right)=\alpha+\beta \ln \left(y_{i 0}\right)+\varepsilon_{i},
$$

gdzie: $y_{i t}$ - rzeczywisty poziom badanego zjawiska w czasie $t ; y_{i 0}-$ bazowy poziom badanego zjawiska w czasie $t ; \alpha$-stała równania regresji; $\beta$ - współczynnik konwergencji; $\varepsilon_{i}$ - błąd losowy o rozkładzie $\varepsilon_{i} \sim N\left(0, \sigma^{2}\right)$.

Uwzględnienie występowania efektów przestrzennych powinno być poprzedzone badaniem ich występowania. Do określenia autokorelacji przestrzennej można wykorzystać współczynnik autokorelacji Ig Morana o postaci [Suchecki (red.) 2010]:

1 Wybór tych autorów nie jest przypadkowy, a mianowicie zajmowali się oni konwergencją przestrzenną lub ich badania wprowadzały poprzez wybór innych cech zmiany w pojmowaniu klasycznym hipotezy konwergencji. 


$$
I g=\frac{N}{\sum_{i=1}^{N} \sum_{j}^{N} w_{i j}} \frac{\sum_{i=1}^{N} \sum_{j}^{N} w_{i j}\left(x_{i}-\bar{x}\right)\left(x_{j}-\bar{x}\right)}{\sum_{i=1}^{N}\left(x_{i}-\bar{x}\right)^{2}},
$$

gdzie: $w_{i j}$ - element macierzy wag $\mathbf{W} ; x_{i}$ - wartość cechy dla obiektu w lokalizacji $i$-tej; $x_{j}$ - wartość cechy dla obiektu w lokalizacji j-tej; $\bar{x}$ - średnia wartość cechy dla wszystkich badanych obiektów przestrzennych; $N$ - liczba wszystkich obiektów objętych badaniem przestrzennym.

Wartości dodatnie współczynnika Morana świadczą o dodatniej autokorelacji przestrzennej, co dowodzi wpływu wartości badanej zmiennej w danej lokalizacji na poziomy tej zmiennej w sąsiednich lokalizacjach. Efekt autokorelacji przestrzennej można przedstawić na diagramie Morana. Wykorzystanie tego wykresu pozwala na wyznaczenie klastrów dla badanych obiektów ze względu na przestrzeń, w jakiej się znajdują. W analizach przeniesiono wyniki autokorelacji przestrzennych na mapę administracyjną Polski, wizualizując reżimy przestrzenne.

W celu uwzględnienia powiązań przestrzennych między regionami zmodyfikowano podstawowy model regresji opisany formułą 1. W konsekwencji uzyskano następujący model:

$$
\ln \left(\frac{y_{i t}}{y_{i 0}}\right)=\alpha+\beta \ln \left(y_{i 0}\right)+\rho \sum_{j=1}^{N} w_{i j} \ln \left(\frac{y_{i t}}{y_{i 0}}\right)+\varepsilon_{i},
$$

gdzie: $w_{i j}$ - jest elementem macierzy wag $\mathbf{W} ; \rho$ - oznacza współczynnik korelacji przestrzennej.

W modelu określonym formułą 3 włączono powiązania przestrzenne, co umożliwiło uwzględnienie wpływu, jaki na zmiany zachodzące w badanym regionie ma zmiana zachodząca w regionach sąsiednich. Uwzględnienie efektów przestrzennych jest możliwe przez zastosowanie odpowiedniej macierzy sąsiedztwa $\mathbf{W}$, która definiuje istniejącą strukturę przestrzenną:

$$
\mathbf{W}=\left[\begin{array}{ccc}
w_{11} & \cdots & w_{1 j} \\
\vdots & \ddots & \vdots \\
w_{i 1} & \cdots & w_{i j}
\end{array}\right],
$$

gdzie: jest elementem macierzy wag $\mathbf{W}$ kwantyfikującym powiązania pomiędzy $i$-tym oraz $j$-tym obiektem przestrzennym.

Podstawy budowy macierzy wag opiera się na zdefiniowaniu sąsiedztwa badanych obiektów, tzn. czy są to obiekty, które charakteryzują się wspólną granicą, lub takie, których położenie definiujemy ze względu na pomiar odległości. Klasyfikację rodzajów macierzy wag przestrzennych ze względu na sposób ich budowy możemy znaleźć w pracach badawczych Getisa i Alstadta [2004]. Najczęściej wykorzysty- 
wana macierz $\mathbf{W}$ to macierz pierwszego rzędu, uwzględniająca obiekty, które mają wspólną granicę. W efekcie sąsiedztwo pierwszego rzędu można określić według następującego schematu:

$$
\begin{cases}w_{i j}=1, & \text { gdy obiekt } i \text {-ty jest sąsiadem obiektu } j \text {-tego } \\ w_{i j}=0, & \text { gdy obiekt } i \text {-ty nie jest sąsiadem obiektu } j \text {-tego }, \\ w_{i j}=0, & \text { gdy } i=j\end{cases}
$$

Określenie postaci macierzy wag jest zagadnieniem bardzo ważnym, ponieważ może zupełnie zmienić strukturę przestrzenną [Florax, Rey 1995]. Oprócz kryterium wspólnej granicy można również rozważać zupełnie inne podejście do problemu, a mianowicie w przypadku kiedy dwa obiekty są położone blisko siebie w przestrzeni, ale nie mają wspólnej granicy, dla określenia ich wzajemnego sąsiedztwa rozważa się kryterium odległości w kilometrach. Zapis matematyczny takiej struktury macierzy $\mathbf{W}$ określono w formule 6:

$$
\left\{\begin{array}{l}
w_{i j}=1, \text { gdy obiekt } i \text {-ty jest oddalony od obiektu } j \text {-tego o } d \text { km lub mniej } \\
w_{i j}=0 \text {,gdy obiekt } i \text {-ty jest oddalony od obiektu } j \text {-tego o więcej niż } d \mathrm{~km} . \\
w_{i j}=0, \text { gdy } i=j \text { (elementy diagonali macierzy sąsiedztwa) }
\end{array}\right.
$$

Jak ważne jest to zagadnienie, może świadczyć fakt, że wielu autorów w swoich pracach, oprócz podstawowego ujęcia tworzenia macierzy wag (formuła 4), określa interakcje przestrzenne poprzez wprowadzenie odległości społecznych [Doreian 1980] lub ekonomicznych [Conley 1999; Pietrzykowski 2011], które oparte są na wzajemnych stosunkach handlowych lub przepływie kapitału pomiędzy badanymi jednostkami przestrzennymi. W pracy wykorzystano podstawową macierz wag $\mathbf{W}$ utworzoną zgodnie $\mathrm{z}$ formułą 5. Przeprowadzono jedynie normalizację wierszową do jedności [Kopczewska 2007]. Uwzględnienie w modelu efektów przestrzennych powinno eliminować efekt autokorelacji składnika losowego, który często występuje w podstawowym modelu regresji (formuła 1) ze względu na opóźnienia czasowe. Model regresji opisany formułą 1 jest estymowany z wykorzystaniem metody najmniejszych kwadratów (MNK). Natomiast uwzględnienie efektów przestrzennych powoduje, że model (patrz formuła 3) należy szacować metodą największej wiarogodności (MNW).

\section{Dane}

W pracy wykorzystano dane dostępne w bazach Eurostatu w latach 2004-2014 (dane roczne) na poziomie NUTS2 dla Polski. W tym okresie Polska była już członkiem Unii Europejskiej. W celu zniwelowania efektu zmiany powodowanej przez akcesję jako rok bazowy wybrano rok 2005. Podobnie postąpiono w przypadku wyboru danych z roku 2007 i 2010, które poprzedzają i kończą okres wystąpienia kryzysu 
ogólnoświatowego. Natomiast wybór roku 2013 do badań wynikał z dostępności w bazach Eurostatu. Wydajność pracy w rolnictwie obliczono dzieląc wartość dodaną brutto w cenach bieżących przez AWU, która jest umowną jednostką nakładów pracy w rolnictwie, oznaczającą ekwiwalent pełnego etatu. W Polsce zgodnie z nomenklaturą GUS przyjęto, że mamy 265 dni roboczych po 8 godzin pracy dziennie, co daje ekwiwalent pełnego etatu wynoszący 2120 godzin pracy w roku, czyli AWU jest obliczane przez podzielenie liczby godzin przepracowanych w ciągu roku przez roczną liczbę godzin odpowiadającą pełnemu etatowi².

\section{Wyniki}

Na wykresie 1 (rys. 1) przedstawiono zmiany zachodzące w wydajności pracy w rolnictwie w podziale na województwa w latach 2005, 2007, 2010 i 2013. Zauważmy, że wydajność pracy w województwach mimo widocznego wzrostu w badanych latach zachowuje swoją strukturę ze względu na poszczególne województwa.

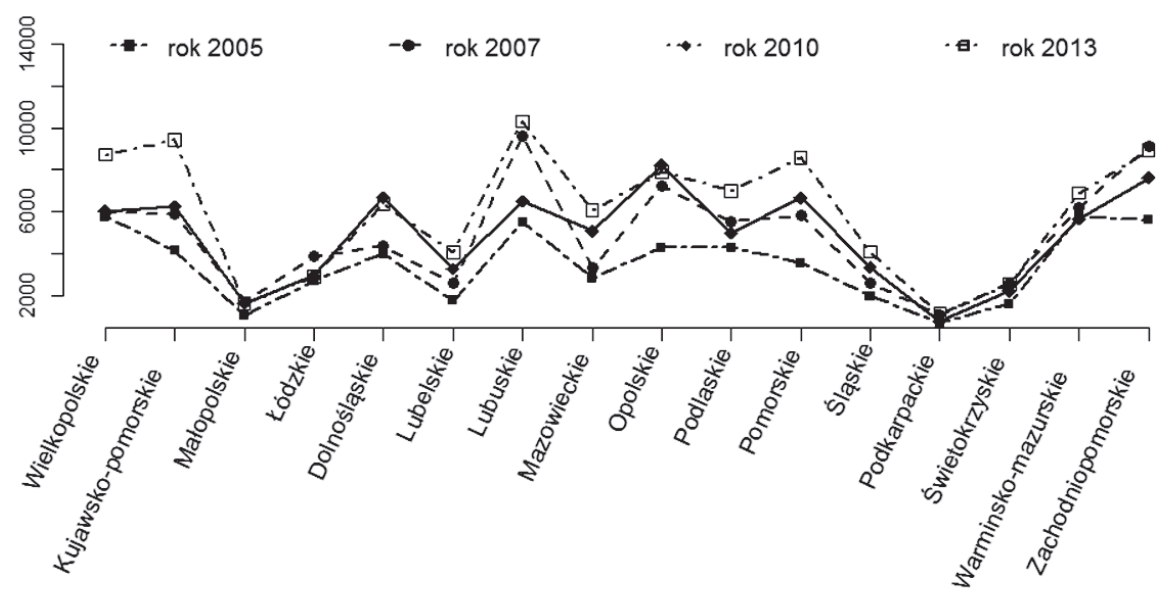

Rys. 1. Wydajności pracy w rolnictwie z podziałem na województwa w okresie od 2005 do 2013

Źródło: opracowanie własne.

Następnie policzono dla wszystkich lat współczynniki korelacji Morana (tabela 1) w celu określenia występowania autokorelacji przestrzennej. Wszystkie uzyskane współczynniki Morana były istotne (patrz: tabela 1 i p-value). Poza tym we wszystkich latach uzyskano dodatnie współczynniki korelacji Morana, co wskazywałoby na tworzenie się klastrów województw o podobnych wartościach wydajności pracy

2 Rozporządzenie Parlamentu Europejskiego i Rady (WE) nr 1166/2008 z dnia 19 listopada 2008 r. w sprawie badań struktury gospodarstw rolnych i badania metod produkcji rolnej oraz uchylające rozporządzenie Rady (EWG) nr 571/88. Tekst mający znaczenie dla EOG, Dz.Urz. UE L 321 z 1.12.2008, s. $14-34$. 
W rolnictwie. Na rysunku 2 przedstawiono klastry ze względu na wydajność pracy w oparciu o koleogramy Morana dla poszczególnych lat. Zauważmy, że struktura klastrów jest bardzo podobna we wszystkich badanych okresach. W pierwszym klastrze (I quarter) są województwa, które charakteryzują się wysoką wydajnością pracy i sąsiadują z województwami o wysokiej wydajności pracy w rolnictwie. Zgadza się to z badaniami innych autorów oraz ogólną wiedzą, że cała zachodnia Polska charakteryzuje się wyższą wydajnością pracy w rolnictwie. W klastrze 2 (II quarter) znalazły się te województwa, które charakteryzują się niską wydajnością pracy, ale sąsiadują z województwami o wysokiej wartości badanej cechy. W roku 2005 jest to tylko województwo podlaskie, natomiast w kolejnych latach dołącza do tego klastra województwo opolskie i mazowieckie. Trzeci klaster (III quarter) zajmują województwa o niskiej wydajności pracy w rolnictwie i które otoczone są przez województwa o niskiej wydajności pracy. Ostatni klaster (IV quarter) to województwo o wysokiej wydajności pracy, które sąsiadują z obiektami o niskiej wydajności. W roku 2005 nie odnotowano takiego województwa, natomiast w roku 2007 było to województwo dolnośląskie, a w latach 2010 i 2013 było to województwo łódzkie.

Następnie obliczono modele regresji w celu oszacowania konwergencji. Jako rok bazowy przyjęto rok 2005, a rokiem badanym był rok 2013. W tabeli 2 przedstawiono wyniki obliczeń dla modelu klasycznego (formuła 1). Współczynnik $\beta$ jest ujemny, ale nieistotny statystycznie. Mimo że wartość współczynnika konwergencji jest ujemna, to nie możemy uznać, że istnieje konwergencja w badanym okresie.

Wynik obliczeń dla modelu $\mathrm{z}$ efektami przestrzennymi zamieszczono $\mathrm{w}$ tabeli 2 . Podobnie jak w klasycznym modelu współczynnik $\beta$ jest ujemny. Jednak nie można stwierdzić istnienia konwergencji typu $\beta$, ponieważ jest on nieistotny $(0,05<0,9401)$.

Podsumowując, nie udało się stwierdzić istnienia efektu konwergencji ze względu na wydajność pracy w województwach w obu badanych modelach. Poprawność modeli badano stosując odpowiednie testy w analizie resztowej. Można jednak zauważyć, że lepszym modelem według kryterium Akaike okazał się model z efektami przestrzennymi (AIC $=-0,0328$ ). Można by się zastanowić, dlaczego nie udało się stwierdzić istnienia konwergencji, skoro widać, że od roku 2005 następuje jednak wzrost wydajności pracy w rolnictwie (rys. 1). Można by stwierdzić, że proces zachodzących zmian ma podobną strukturę w poszczególnych województwach. Potwierdza to układ klastrów uzyskanych w wyniku przeprowadzonej analizy w oparciu o współczynnik Morana (rys. 2). W celu stwierdzenia, jak kształtują się średnie zmiany w poszczególnych latach, obliczono przedziały ufności dla wydajności pracy w rolnictwie i przedstawiono je na wykresie (rys. 3). Na osi pionowej zaznaczono średni poziom wydajności pracy w rolnictwie w województwie, a na osi poziomej zamieszczono cztery badane lata. Krzywa na wykresie łączy średni przebieg zjawiska w poszczególnych latach. Widać, że od roku 2005 do roku 2013 mamy ciągły wzrost średniej wydajności pracy w rolnictwie. Dla każdego roku zaznaczono przedziały ufności w postaci „wąsów” odchodzących od wartości średniej. Zauważmy, 
Tabela 1. Współczynniki Morana

\begin{tabular}{|c|c|c|c|}
\hline Rok & $I g$ & Błąd standardowy statystyki $I g$ & $p$-value \\
\hline 2005 & 0,6185 & 4,4365 & $9,14 \mathrm{e}-06$ \\
\hline 2007 & 0,5184 & 3,8691 & $1,09 \mathrm{e}-04$ \\
\hline 2010 & 0,5937 & 4,3128 & $1,61 \mathrm{e}-05$ \\
\hline 2013 & 0,6088 & 4,3786 & $1,19 \mathrm{e}-05$ \\
\hline
\end{tabular}

Źródło: obliczenia własne.
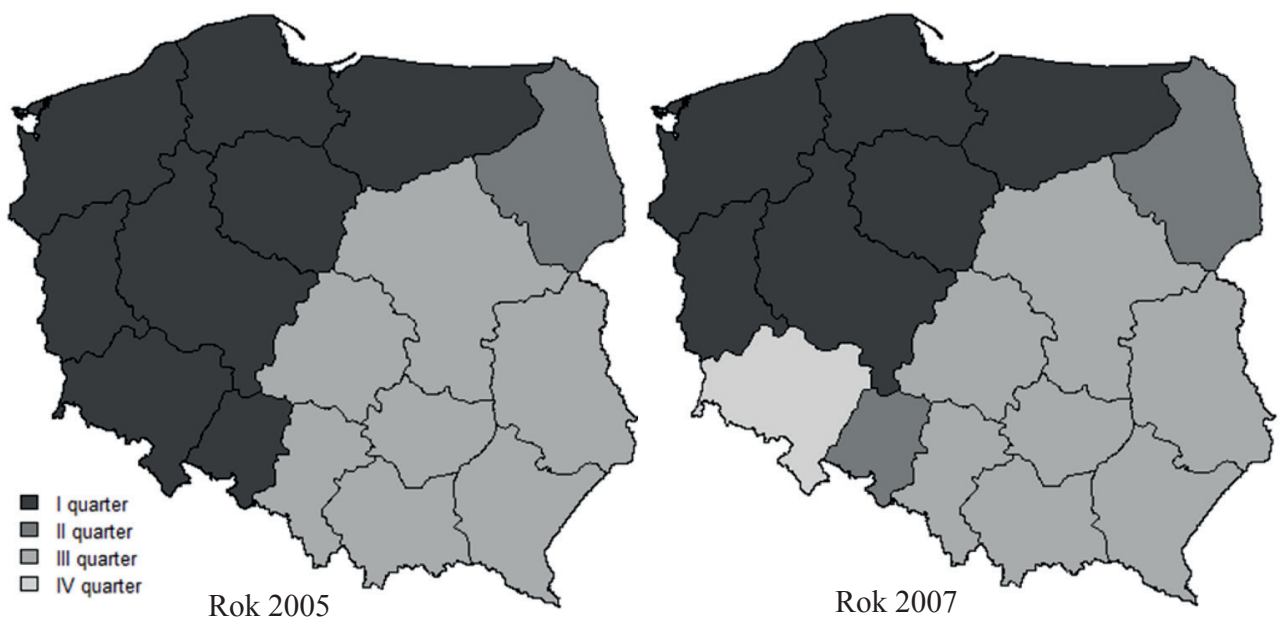

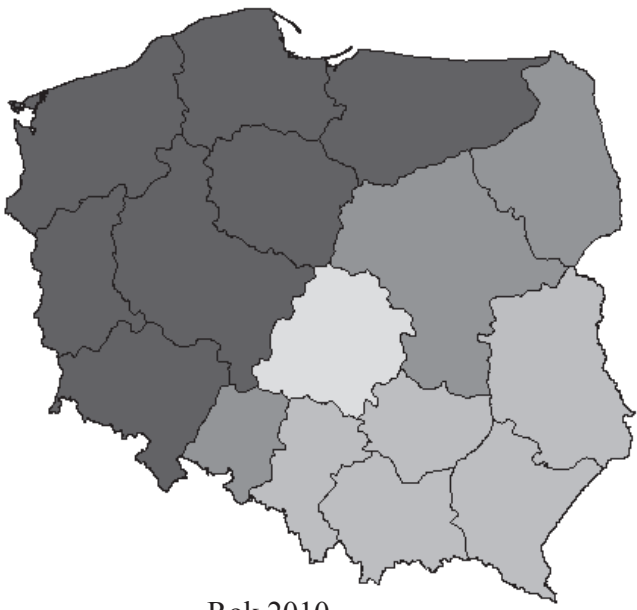

Rok 2010

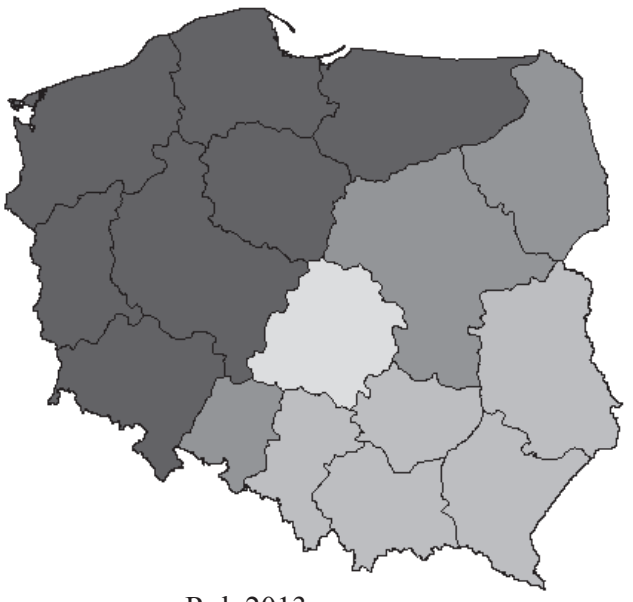

Rok 2013

Rys. 2. Wizualizacja diagramu Morana dla wydajności pracy w rolnictwie w okresie od 2005 do 2013 na mapie Polski

Źródło: opracowanie własne. 
Tabela 2. Wyniki estymacji i weryfikacji modelu podstawowego (formuła 1)

\begin{tabular}{|c|c|c|c|c|}
\hline Parametry & Ocena parametru & Błąd standardowy & Statystyka $t$ & $p$-value \\
\hline$\alpha$ & 0,7585 & 0,7587 & 1,1801 & 0,3341 \\
\hline$\beta$ & $-0,0265$ & 0,0947 & $-0,2792$ & 0,7842 \\
\hline AIC $=3,2814$, błąd standardowy reszt $=0,2376$ \\
\hline
\end{tabular}

Źródło: obliczenia własne.

Tabela 3. Wyniki estymacji i weryfikacji modelu z efektami przestrzennymi (formuła 3)

\begin{tabular}{|c|c|c|c|c|}
\hline Parametry & Ocena parametru & Błąd standardowy & Statystyka $z$ & $p$-value \\
\hline$\alpha$ & 0,5682 & 0,3245 & 1,7506 & 0,0800 \\
\hline$\beta$ & $-0,0031$ & 0,0405 & $-0,0751$ & 0,9401 \\
\hline AIC $=-0,0328$, błąd standardowy reszt $=0,0284$ \\
\hline
\end{tabular}

Źródło: obliczenia własne.

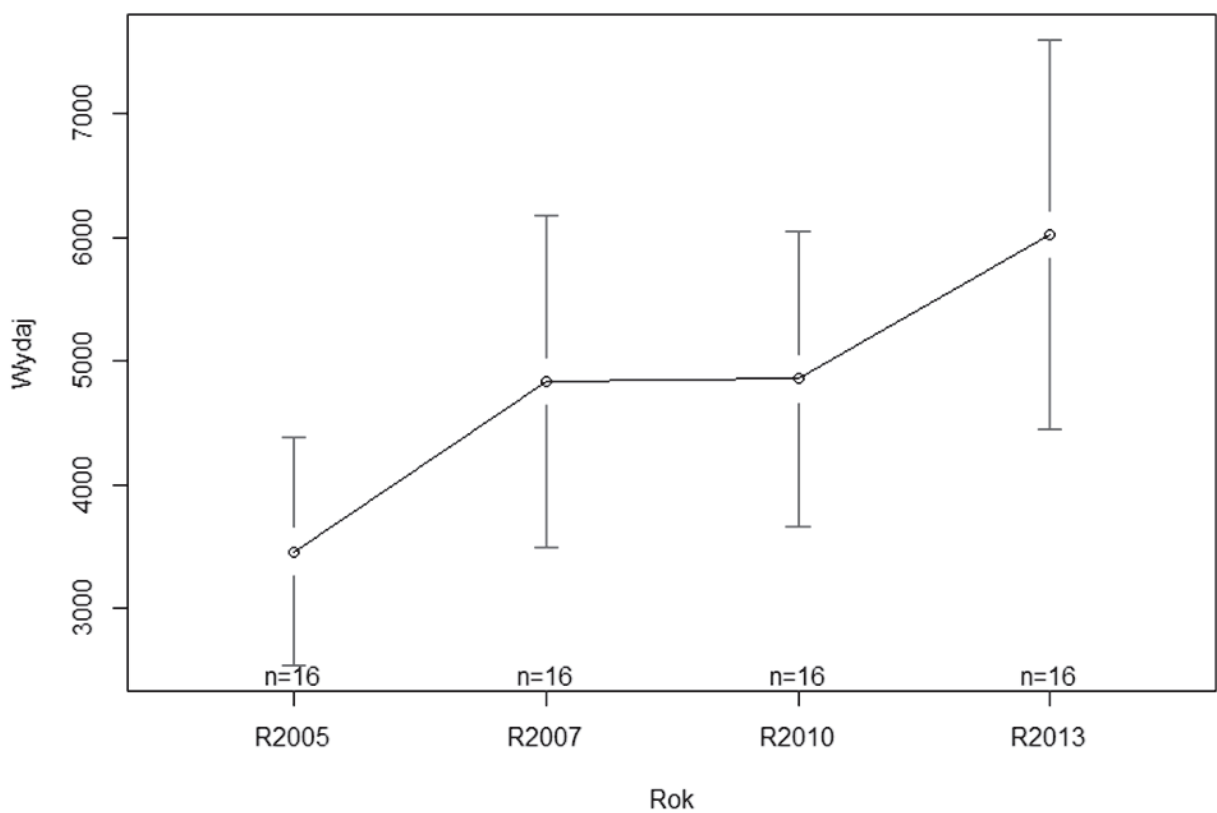

Rys. 3. Przedziały ufności dla średnich wydajności pracy w rolnictwie w okresie od 2005 do 2013 Źródło: opracowanie własne.

że końce przedziałów w poszczególnych latach zachodzą na siebie, a zatem nie można rozróżnić średniej wydajność pracy w rolnictwie w latach, co w konsekwencji może być przyczyną nieuzyskania istotności dla współczynnika konwergencji. 
Inną przyczyną może być mała liczba danych przyjęta w analizie. Rozwiązaniem byłoby wykonanie obliczeń na poziomie powiatów lub gmin, ale wymagałoby to uzyskania danych na niższym poziomie agregacji.

\section{Zakończenie}

Polska w porównaniu z rozwiniętymi gospodarczo państwami Unii Europejskiej jest państwem o jednej z najniższych wydajności pracy w rolnictwie. Przyczyny takiego stanu upatruje się w dużych zasobach siły roboczej, silnym rozdrobnieniu gospodarstw, niskim wyposażeniu w środki kapitałowe, co w konsekwencji prowadzi do niskiej produktywności czynników wytwórczych [Gołaś, Kozera 2008]. Konsekwencją tego stanu, odczuwalną przez ludność rolniczą, są jej niskie dochody. Rozwiązania tej kwestii upatruje się w zmniejszeniu lub całkowitym zniwelowaniu socjalnej roli zatrudnienia w gospodarstwach rolnych, w szczególności w małych gospodarstwach [Kołodziejczak 2016], poprzez zatrudnienie pracowników rolnych w działach pozarolniczych.

W wyniku przeprowadzonych analiz nie udało się stwierdzić istnienia konwergencji na poziomie NUTS2 w wydajności pracy w rolnictwie. Jednak jak podaje Czyżewski, w przypadku rolnictwa proces konwergencji ma dość ograniczony charakter i w odniesieniu do tego sektora gospodarki, ze względu na stosowanie zróżnicowanych rozwiązań w polityce jego wsparcia, może wystąpić proces hamowania konwergencji jako takiej. Poza tym zjawisko konwergencji nie jest jednorodne i powinno być rozważane $\mathrm{z}$ uwzględnieniem istniejących ograniczeń $\mathrm{w}$ zakresie jego występowania [Czyżewski, Kułyk 2009].

Należy jednak nadmienić, że udało się uzyskać informacje o przestrzennym charakterze badanego zjawiska, wykorzystując współczynnik korelacji Morana. Stwierdzono występowanie stałej struktury klastrów dla województw od roku 2004. W wyniku przeprowadzonych analiz stwierdzono, że wydajność pracy w rolnictwie w województwach tworzy wyraźne klastry, czyli ich grupowanie charakteryzuje się wyraźną prawidłowością. Można powiedzieć, że województwa zachodniej Polski tworzą klastry złożone z obiektów o wysokiej wydajności pracy z województwami o takim samym wysokim poziomie tej cechy. Natomiast województwa z części wschodniej tworzą klastry charakteryzujące się podziałem wskazującym na grupowanie województw o niskiej wydajności pracy z niskimi wartościami tej cechy. Porównując wartości współczynnika Morana, stwierdzono, że w całym badanym okresie ta tendencja utrzymuje się na stałym poziomie, co może wskazywać na taki sam wpływ województw na siebie ze względu na wydajność pracy w rolnictwie. 


\section{Literatura}

Anselin L., Rey S.J., 1997, Introduction to the special issue on spatial econometrics, Int. Reg. Sci. Rev., 20, s. 1-7.

Baer-Nawrocka A., Markiewicz N., 2012, Procesy konwergencji/dywergencji w zakresie wydajności pracy $w$ rolnictwie Unii Europejskiej - analiza regionalna, Journal of Agribusiness and Rural Development, 3(25), s. 13-23.

Barro R., Sala-i-Martin X., 1992, Convergence, Journal of Political Economy, 100, s. 223-251.

Baumol W., 1986, Productivity growth, convergence, and welfare: What the long-run data show, American Economic Review, 76, s. 1072-1085.

Ciołek D., 2003, Badanie konwergencji krajów Europy Środkowo-Wschodniej z wykorzystaniem danych panelowych, [w:] Piłatowska M. (red.), Dynamiczne modele ekonometryczne, Wydawnictwo Uniwersytetu Mikołaja Kopernika, Toruń, s. 329-342.

Conley T.G., 1999, GMM estimation with cross sectional dependence, Journal of Econometrics, 92(1), s. $1-45$.

Czyżewski A., Kułyk P., 2009, Konwergencja czy dywergencja mechanizmów wsparcia sektora rolnego?, Zeszyty Naukowe Szkoły Gospodarstwa Wiejskiego w Warszawie, Problemy Rolnictwa Światowego, t. 8(23), s. 41-51.

Doreian P., 1980, Linear models with spatial distributed data. Spatial disturbances or spatial effects, Sociological Methods and Research, 9, s. 29-60.

Florax R.J.G.M., Rey S.J., 1995, The impacts of misspecied spatial interaction in linear regression models, [w:] Anselin L., Florax R.J.G.M. (eds.), New Directions in Spatial Econometrics, Springer, Berlin.

Gawlikowska-Hueckel K., 2002, Konwergencja regionalna w Unii Europejskiej, Gospodarka Narodowa, $\mathrm{nr}$ 10, s. 91-113.

Gerschenkron A., 1962, Economic Backwardness in Historical Perspective, Harvard University Press, Cambridge.

Getis A., Alstadt J., 2004, Constructing the Spatial Weights Matrices Using a Local Statistics, Geographical Analysis, t. 36(2), s. 147-163.

Gołaś Z., Kozera M., 2008, Strategie wydajności pracy w gospodarstwach rolnych, JARD 1(7), s. 73$-87$.

Kisiała W., 2016, Zmiany nierówności poziomu rozwoju gospodarczego powiatów w Polsce-Konwergencja czy dywergencja, Prace Naukowe Uniwersytetu Przyrodniczego we Wrocławiu, nr 418, s. $127-135$.

Knight M., Norman L., Delano V., 1993, Testing the neoclassical theory of economic growth: a panel data approach, IMF Staff Papers, 40(3), s. 512-541.

Kołodziejczak W., 2016, Nadwyżka zatrudnienia w polskim rolnictwie-projekcja na tle państw Unii Europejskiej, Zeszyty Naukowe Szkoły Głównej Gospodarstwa Wiejskiego w Warszawie, Problemy Rolnictwa Światowego, t. 16 (XXXI), z. 1, 129-141.

Kopczewska K., 2007, Ekonometria i statystyka przestrzenna z wykorzystaniem programu R CRAN, CeDeWu, Warszawa.

Kossowski T., 2009, Konwergencja przestrzenna - aspekty teoretyczne. Praktyczne aspekty badań regionalnych - varia, t. 2, Biuletyn Instytutu Geografii Społeczno-Ekonomicznej i Gospodarki Przestrzennej Uniwersytetu im. Adama Mickiewicza w Poznaniu, nr 8, seria: Rozwój Regionalny i Polityka Regionalna, s. 7-20.

Olejnik A.A., 2014, Empiryczne modele wzrostu gospodarczego z efektami przestrzennymi, Acta Universitatis Lodziensis, Folia Oeconomica, 5 (306), s. 75-90.

Mankiw G., Romer D., Weil D., 1992, A contribution to the empirics of economic growth, Quarterly Journal of Economics, vol. 107(2), s. 407-437. 
Modranka E., 2012, Zastosowanie modeli panelowych $w$ analizie warunkowej konwergencji typu $\beta$ z uwzględnieniem zależności przestrzennych, Collegium of Economic Analysis Annals, issue 26, s. 61-72.

Pietrzykowski R., 2011, Koncepcja i zastosowanie modyfikacji macierzy wag w przestrzennych badaniach ekonomicznych, Metody Ilościowe w Badaniach Ekonomicznych, vol. 12, s. 270-278.

Rey S.J., 2001, Spatial empirics for economic growth and convergence, Geographical Analysis, 33(3), s. $195-214$.

Sala-i-Martin X., 1990, On Growth and States, PhD thesis, Harvard University.

Sala-i-Martin X., 1996, The classical approach to convergence analysis, The Economic Journal, vol. 106, s. 1019-1036.

Suchecki B. (red.), 2010, Ekonometria przestrzenna. Metody i modele analizy danych przestrzennych, C.H. Beck, Warszawa.

Wicki L., 2012, Konwergencja czy dywergencja w zakresie stosowania nasion kwalifikowanych w Polsce (analiza regionalna), Roczniki Naukowe Stowarzyszenia Ekonomistów Rolnictwa i Agrobiznesu, t. 14, z. 1, s. 539-544.

Wójcik P., 2004, Konwergencja regionów Polski w latach 1990-2001, Gospodarka Narodowa, nr 11-12 , s. 69-86. 